\title{
Locating Ground-Water Discharge in the Hanford Reach of the Columbia River
}

David R. Lee ${ }^{1}$

David R. Geist ${ }^{2}$

Kay Saldi ${ }^{2,3}$

Dale Hartwig ${ }^{1}$

Tom Cooper ${ }^{2}$

March 1997

Prepared for the U.S. Department of Energy under Contract DEAC06-76RLO 1830

Atomic Energy of Canada Ltd. Chalk River Laboratories
Pacific Northwest National Laboratory Operated for the U.S. Department of Energy by Battelle Memorial Institute
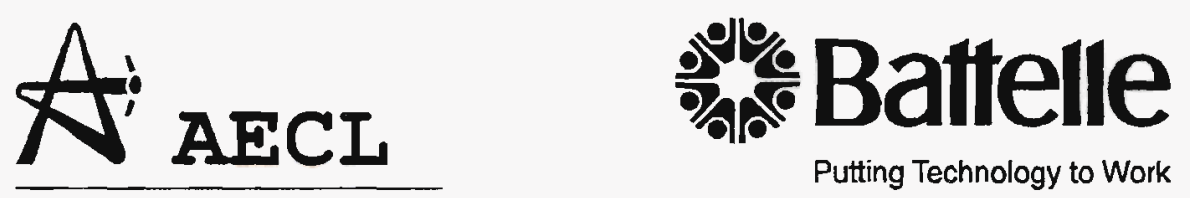

${ }^{1}$ Environmental Research Branch, Chalk River Laboratories, Atomic Energy of Canada, Ltd., Chalk River, Ontario, Canada, KOJ 1JO, LeeD@AECL.ca, phone: (613) 584-3311

${ }^{2}$ Environmental Technology Division, Pacific Northwest National Laboratory, Post Office Box 999, MS K6-85, Richland, Washington, 99352

${ }^{3}$ Currently with King Conservation District, 935 Powell Ave. S.W., Renton, WA 98055 


\section{Summary}

A bottom-contacting probe for measuring electrical conductivity at the sediment-water interface was used to scan the bed of the Columbia River adjacent to the Hanford Site in southeast Washington State during a 10-day investigation. Four river-sections, each about a kilometer in length, were scanned for variations in electrical conductivity. The probe was towed along the riverbed at a speed of $1 \mathrm{~m} / \mathrm{s}$ and its position was recorded using a Global Positioning System.

The bottom tows revealed several areas of elevated electrical conductivity. Where these anomalies were relatively easy to access, piezometers were driven into the riverbed and porewater samples were taken. The upward flux of ground water at these locations was tested by measuring porewater electrical conductivity and, in selected ones, by measuring concentrations of contaminants. At these locations, porewater electrical conductivity ranged from 125 to $380 \mu \mathrm{S} / \mathrm{cm}$ and surface water electrical conductivity ranged from 111 to $150 \mu \mathrm{S} / \mathrm{cm}$.

The piezometers, placed in electrical conductivity "hotspots," yielded chemical or isotopic data consistent with previous analyses of water taken from monitoring wells and visible shoreline seeps. Tritium, nitrate, and chromium exceeded water quality standards in some porewaters. The highest tritium and nitrate levels were found near the Old Hanford Townsite at $120,000 \mathrm{pCi} / \mathrm{L}( \pm$ $8,850 \mathrm{pCi} / \mathrm{L}$ total propagated analytical uncertainty) and $28,000 \mu \mathrm{g} / \mathrm{L}( \pm 5,880$ $\mu \mathrm{g} / \mathrm{L}$ ), respectively. The maximum chromium (total and hexavalent) levels were found near $100-\mathrm{H}$ reactor area where unfiltered porewater total chromium was $1,900 \mu \mathrm{g} / \mathrm{L}( \pm 798 \mu \mathrm{g} / \mathrm{L})$ and hexavalent chromium was 20 $\mu \mathrm{g} / \mathrm{L}$.

The electrical conductivity probe provided rapid, cost-effective reconnaissance for ground-water discharge areas when used in combination with conventional piezometers. It may be possible to obtain quantitative estimates of both natural and contaminated ground-water discharge in the Hanford Reach with more extensive surveys of the river bottom. 


\section{Acknowledgments}

Roger Dirkes (PNNL) recognized the potential of this method and arranged for partial financial support from the Department of Energy (DOE) through the Public Safety and Resource Protection Program (Dana Ward, DOE-RL Program Manager). In addition, the Bonneville Power Administration (BPA) also provided funding through Pacific Northwest National Laboratory's Fish and Wildlife Technical Assistance Project, Salmon Modeling Task (Debbie Docherty, BPA Contracting Technical Officer). Special thanks to our funding sponsors. Rick Janzen (AECL Research) actively promoted the effort in the early stages and Rick, Kathy Lavender and Jill Farris (PNNL) looked after administrative details. Jeff Cheung (AECL Research) developed the software to compile data in the field, process it in the office, and display it in the report. Ken Whitlock (AECL Research) helped design the electrical conductivity probe and manufactured piezometer drive tips. Tim Hanrahan and Richard Visser (PNNL) performed the GIS work and created the color maps. Evan Dresel, Vince Vermuel, Greg Patton, Dennis Dauble, Paul Thorne, and Sue Blanton (PNNL) assisted in the field and/or reviewed the report. 


\section{Contents}

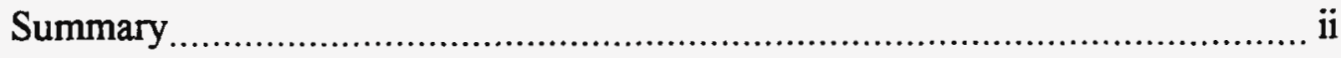

Acknowledgments …................................................................................ ii

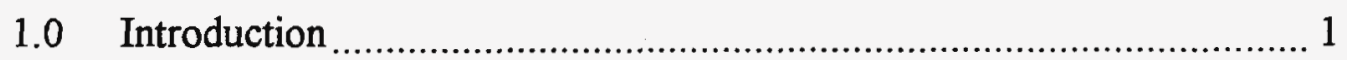

2.0 Study Area

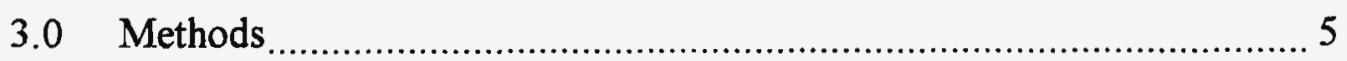

3.1 Electrical Conductivity Probe and Standardization ..................... 5

3.2 Mapping of Electrical Conductivity Variations ........................... 6

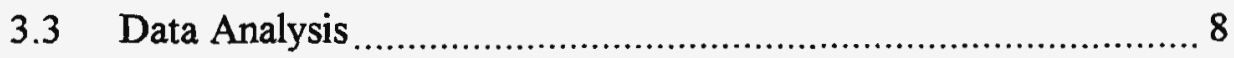

3.4 Confirmation of Electrical Conductivity Probe Survey Results .... 8

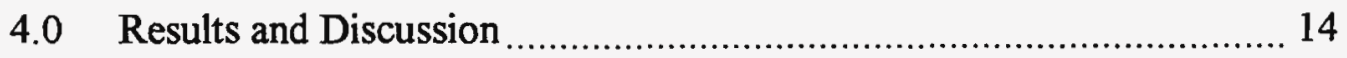

4.1 General Electrical Conductivity Surveys .................................. 14

4.2 Site Specific Results ................................................................. 17

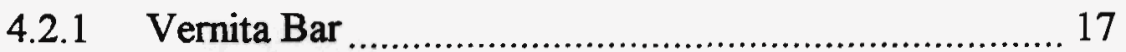

4.2.2 Upper and Lower 100-H ........................................ 18

4.2.3 Locke Island and White Bluffs Slough ............................. 27

4.2.4 Old Hanford Townsite ................................................. 31

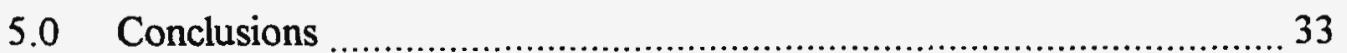

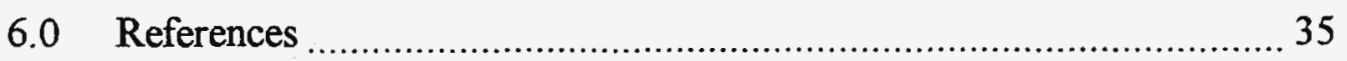




\section{Figures}

3.1 Electrical conductivity probe 5

3.2 Calibration curves for the two probes used in the study ....................6 6

3.3 River locations of conductivity measurements ............................ 7

4.1 Electrical conductivity measurements - Vernita Bar Area ................. 19

4.2 Electrical conductivity measurements - Upper and Lower 100-H Areas

4.3 Electrical conductivity measurements - Lower 100-H Area

4.4 Electrical conductivity measurements - Upper 100-H Area

4.5 Electrical conductivity measurements - Locke Island and White Bluffs Slough Area 28

4.6 Electrical conductivity measurements - Locke Island Area 30

4.7 Electrical conductivity measurements - Hanford Townsite Area 32

\section{Tables}

3.1 Extended analyte list for Upper 100-H and Old Hanford Townsite samples

4.1 Piezometer field data collected immediately following installation of riverbed piezometers 16

4.2 Results of radiological analysis for tritium, strontium-90 (90Sr), isotopic uranium (234U, 235U, and 238U), and technetium-99 (99Tc) from unfiltered water samples taken from piezometers near the Old Hanford Townsite (H2) and Upper 100-H Area (UH1, UH13, and $\mathrm{UH} 14$ )

4.3 Results of analysis for nitrate, total chromium, and hexavalent chromium from unfiltered water samples taken from piezometers near the Old Hanford Townsite (H2) and Upper 100-H Area (UH1, UH13, and UH14) 


\subsection{Introduction}

The study of the interaction between ground water and surface water within the cobble bed material of large rivers is of great interest to hydrogeologists and ecologists. However, a major obstacle in providing more detailed information on ground-water/surface-water interactions is that installation of monitoring and sampling devices in many rivers is still problematic (Dahm and Valett 1996).

Deciding where to place conventional sampling instruments, (e.g., piezometers) is complicated. At many locations, seepage is expected to occur through the riverbed. Heterogeneity of sediment permeability and spatial and temporal variations of morphometry, current, and river stage make it difficult to determine actual points of discharge. Without knowing these points of discharge, one can not obtain an accurate measurement of the concentration or migration rate of a contaminant. Conventional sampling can require great expenditures, much of it later realized as misplaced in areas of little or no significance for ground-water monitoring. Even where a monitoring network is properly located, data analysis of widely spaced points can require a large degree of interpolation and can result in great uncertainty (e.g., a stringer of high flow that is not sampled by the network). Thus, the ability to scout the river bottom for ground-water discharge locations prior to installing sampling equipment would be beneficial.

We report the first application of a rapid reconnaissance method for locating ground-water discharge in cobble-bottomed rivers. A bottomcontacting, electrical conductivity probe was towed along the bed of the Columbia River and used to target areas for hydrogeological and geochemical analyses. This technique was previously applied in northern Ontario (Lee and Dal Bianco 1994) where the river was smaller and the bottom substrate was composed primarily of gravel material.

The probe technique requires that the electrical conductivity of surface water and ground water differ. This technique provides a qualitative reconnaissance over large areas of river bottoms, especially in areas that are not accessible or that are impossible for conventional ground-water studies. The reconnaissance data can be used to decide optimal locations for quantitative point sampling to determine actual hydraulic conditions and contaminant flux. Thus, electrical conductivity probe results can reduce the amount of arbitrary sampling, help focus efforts in areas of potential impact, or provide evidence that impact is negligible. 
The procedure involves the towing of compact, bottom-contacting probes behind a small, outboard-powered boat. This provides a continuous record of electrical conductivity along the bottom sediments of the river and of geographical position. If specific contaminants are associated with ground water that is more electrically conductive than the local surface water, then the electrically conductive areas are tested for discharge indicators (e.g., high dissolved solids, upward hydraulic potentials and ground-water contaminants). If discharge is indicated, the area can be characterized chemically, isotopically and hydrogeologically to determine sources and transport times.

The primary objectives of this study were to 1) evaluate the potential for locating the submerged ground-water discharges in variable flow regimes and diverse river substrate characteristics using an electrical conductivity probe developed at Chalk River Laboratories, Atomic Energy of Canada, Limited (AECL), and, if feasible, 2) collect quantitative information on the spatial characteristics of ground-water plumes that enter the river along the Hanford Reach. 


\subsection{Study Area}

The U.S. Department of Energy's (DOE) Hanford Site lies north of the confluence of the Yakima, Snake, and Columbia rivers in the semi-arid region of southeastern Washington State. The Site occupies an area of approximately $1,450 \mathrm{~km}^{2}$ and is home to nine deactivated plutonium production reactors. Operations at the Hanford Site historically included uranium fuel preparation, nuclear reactor operations, fuel reprocessing, plutonium recovery, and waste storage and disposal (Neitzel 1996). Current Site operations focus on waste management and environmental restoration.

The Columbia River is the fourth largest river by drainage area in North America (Shiklomanov 1993) and is the dominant surface-water body on the Hanford Site. The Hanford Reach is the last "free-flowing" portion of the Columbia River in the United States and contains numerous important ecological resources (Geist 1995). Based on ground-water and surface-water monitoring, traces of various contaminants, both radiological and nonradiological, are known to enter the Columbia River along the Hanford Reach. In addition to direct discharges of liquid effluents from Hanford facilities (Dirkes and Hanf 1995), contaminants in ground water from past Hanford discharges to the ground are known to seep into the river. The Columbia River is the natural discharge area for the unconfined aquifer underlying the Hanford Site (Dresel et al. 1995). Although the overall impact of groundwater discharge on river concentrations is considered minimal, localized shoreline springs containing contaminants have been noted (McCormack and Carlile 1984; Dirkes 1990). Where such springs emerge through river-covered sediments, the springs could produce localized, negative impacts on the eggs and fry of salmon when spawning nests are built in close proximity. These springs could also affect the young of other spawning fish species, molluscs, insects, and other benthic organisms.

One of the less-studied aspects of ground-water flow at the Hanford Site is the flux of water and solutes to the Columbia River. Considering its ecological, aesthetic, and recreational values, and the history of nuclearproduction activities along this reach, the DOE and other Hanford stakeholders are attempting to address the extent that ground water is diluted between monitoring wells on land and seepage into the river and whether the existing network of wells provide a sufficient framework for assessing impacts of ground water on the river. Of special concern is the possible impact of contaminants at spawning areas of fall chinook salmon (Oncorhynchus tshowytscha) (Geist et al. 1994). 
Because the Columbia River is located in a regional topographic low, the net natural flow of ground water is toward and directly into the river. However, because the surrounding lands are arid, local infiltration is minimal and the movement of ground-water contaminant plumes is quite slow. Moreover, there are places where river morphometry induces a net local flow from river to riverbed (Peterson and Johnson 1992; Geist et al. 1997), and thereby into the surrounding saturated zone. This, along with man-induced recharge could increase the rate of ground-water migration to the river that would exceed that resulting from natural infiltration alone. As a result of hydroelectric power generation upstream, there are fluctuations in river stage above and below the mean ground-water level. This induces a cycle of alternating recharge and discharge with consequent dispersion of solutes within the surficial ground-water zone. However, dilution would not reduce the total solute flux to the river; this could only be achieved through other processes (e.g., precipitation or biodegradation in the near-river sediments).

At some shoreline locations there are seepage faces and discrete springs. These seeps are most obvious when the river level is falling. Seeps have been sampled and analyzed (McCormack and Carlile 1984; Dirkes 1990; Peterson and Johnson 1992; DOE 1992), however, a lack of visible seeps does not indicate the absence of seepage. Ground water simply takes the shortest, least resistant, path to the river. Only where low permeability materials lie beneath these aquifers, or between these aquifers and the river, would visible seeps be expected to occur. While ground water can easily be sampled at shoreline seeps, ground water can also be sampled on the riverbed. Because of the four or more orders of magnitude variation in permeability, the spatial distribution of discharge is expected to be complex. 


\subsection{Methods}

\subsection{Electrical Conductivity Probe and Standardization}

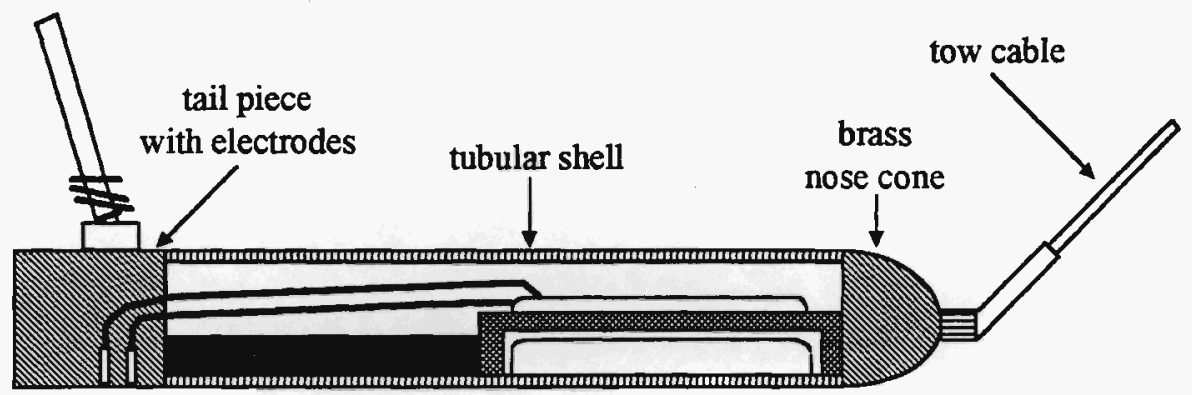

Figure 3.1. Electrical conductivity probe.

The electrical conductivity probe (Figure 3.1 ) consisted of a tubular shell, brass nose cone, tail piece with electrodes, and tow cable as described by Lee and Beattie (1991). The probe measures electrical conductivity and outputs these values in millivolts (mV). To convert probe values to electrical conductivity in micro-Siemens per $\mathrm{cm}(\mu \mathrm{S} / \mathrm{cm})$, four electrical conductivity standards were measured at the end of each 4 to $6 \mathrm{hr}$ surveying session. River water was used as the first standard, and the remaining three were made by dissolving potassium chloride in river water. The data from each set of standard measurements was plotted, and a best fit was determined (Figure 3.2). Two probes were used, one constructed of brass and one of steel. The responses of the two probes differed, but were reasonably close in the range of electrical conductivity values measured in the Columbia River surveys.

The vertical lines in Figure 3.2 show the ranges for the color codes used to plot the recorded electrical conductivity. River bottom values ranged from 40 $\mathrm{mV}$ to $50 \mathrm{mV}$ with some unusually high readings over $60 \mathrm{mV}$. For the steel probe, a reading of $40 \mathrm{mV}$ corresponded to $98 \mu \mathrm{S} / \mathrm{cm}$ and for the brass probe a reading of $40 \mathrm{mV}$ corresponded to $101 \mu \mathrm{S} / \mathrm{cm}$. A $60 \mathrm{mV}$ reading on the steel and brass probes were 168 and $153 \mu \mathrm{S} / \mathrm{cm}$, respectively. Considering the qualitative nature of the targeting done with these probes, these differences, which were at most $9 \%$, had no practical significance. Therefore no distinction was made on the maps as to which probe was used for the various lines. River water was also used as a check on probe response every $1 / 2$ hour during the surveying. 


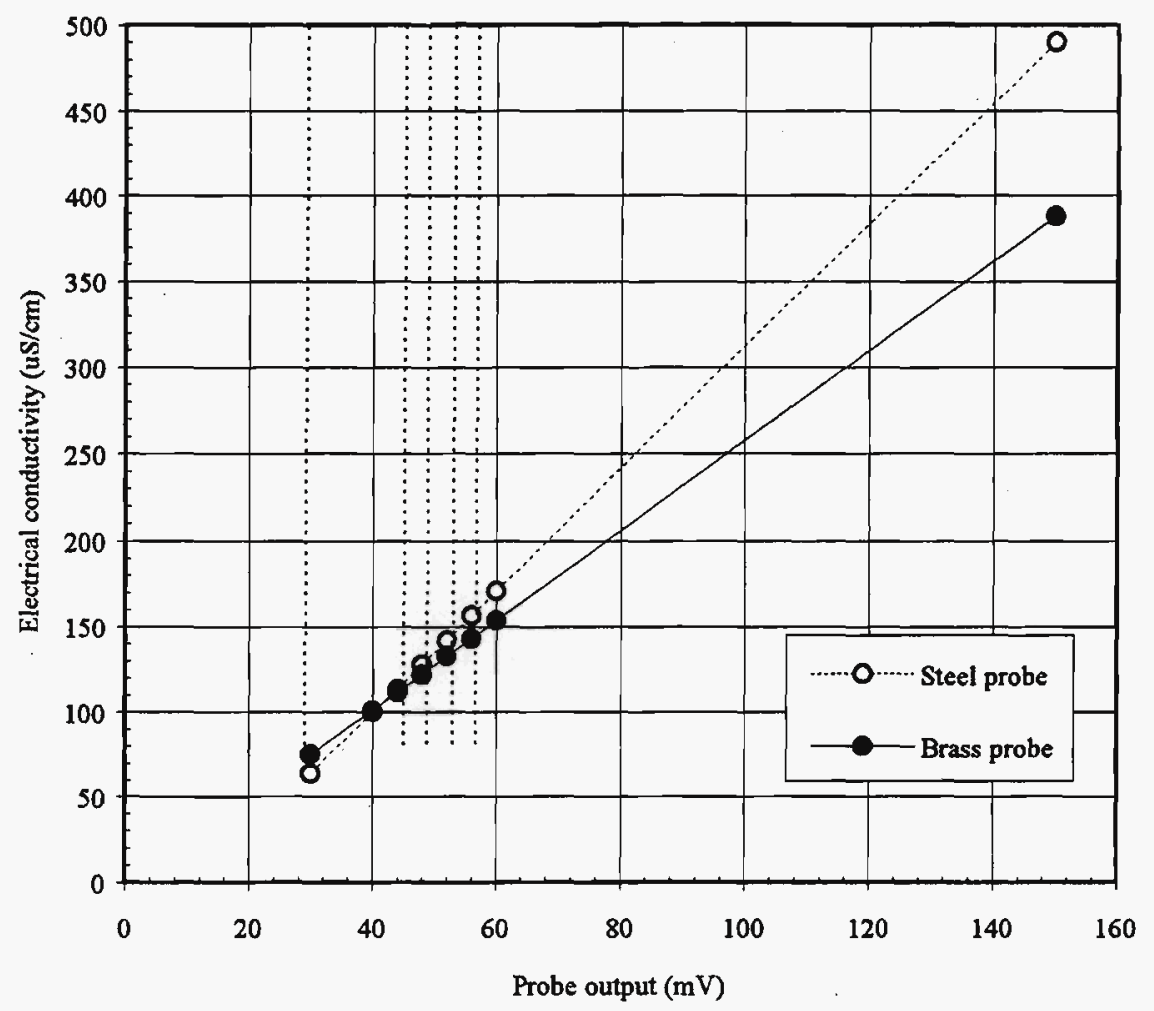

Figure 3.2. Calibration curves for the two probes used in the study.

\subsection{Mapping of Electrical Conductivity Variations}

River locations where electrical conductivity measurements were performed using the electrical conductivity probe are shown in Figure 3.3. From upstream to downstream, the four study sites were: Vernita Bar, 100-H Area (Upper and Lower), Locke Island/White Bluffs Slough, and Old Hanford Townsite (Figure 3.3). The electrical conductivity probe was towed along several lines parallel to shore at each study site. In areas of elevated electrical conductivity, 26 piezometers were installed to determine whether high values of electrical conductivity, revealed locations of ground-water discharge containing higher solute concentrations than the river. 


\section{River Locations of Conductivity Measurements}

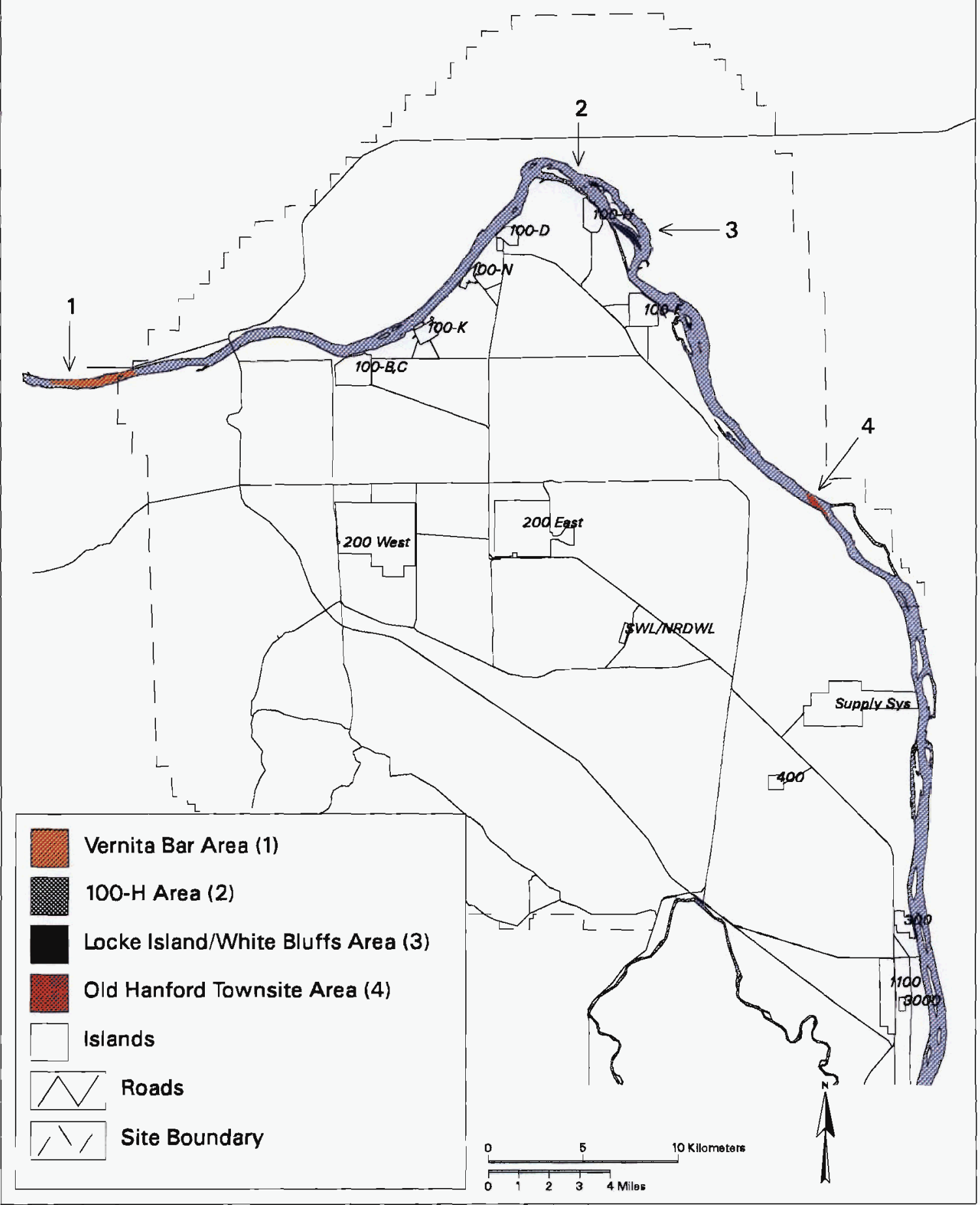


The electrical conductivity probe survey involved two people in a single boat. The data acquisition system provided a real-time strip chart image of results and a record of data. The strip chart image enabled the operators to form mental images of results within the study area, and to deploy marker floats in areas of interest. Custom software, prepared using LabWindows in C, was used to record input from the probe.

Position records were obtained using a Trimble GeoExplorer Global Positioning System (GPS) receiver with a collection rate of one point every two seconds. The electrical conductivity was recorded 2 times each second. The position files were differentially corrected using data from a base station located on the Hanford site, giving 0 to 5 meter accuracy. The probe data acquisition system and GPS receiver were started simultaneously when surveying began. Thus, the probe electrical conductivity and position files were merged based on the clock record of each file using software written by AECL personnel. The software also corrected for time offsets between data and interpolated between position points so that each probe data point had a unique position. The base map of the river was digitized from U.S. Geological Survey topographic maps that show the river at high discharge. During the electrical conductivity surveys at least one line was run close to shore in water about $0.4 \mathrm{~m}$ deep and often within about $10 \mathrm{~m}$ of the shoreline. Therefore, the nearshore line approximated the river shoreline at the time of the work. However, this was not the case at Vernita Bar, where the difference between the nearshore survey line and the shoreline was as much as $250 \mathrm{~m}$ at one location and less than $250 \mathrm{~m}$ elsewhere.

\subsection{Data Analysis}

The first step of data processing was conversion of the boat position, boat direction and cable length to the position of the electrical conductivity probe corresponding to each probe measurement. The probe was assumed to have followed the boat by a distance equal to the length of cable. The cable length was greater than the water depth by at least a factor of four, which resulted in a measurement error below 2.8 percent (i.e., less than $2 \mathrm{~m}$ error). Data analysis employed software customized and developed by AECL personnel (J. Cheung, AECL, personal communication).

\subsection{Confirmation of Electrical Conductivity Probe Survey Results}

To quantify and evaluate electrical conductivity probe results, measurements of hydraulic head relative to the river were made with small piezometers (Lee and Cherry 1978; Lee and Welch 1989). Every effort was made to place piezometers directly on the lines surveyed with the electrical 
conductivity probe. The piezometers also provided ground water for electrical conductivity and chemical analyses.

Following piezometer development, a 50-mL sample of sediment porewater was collected from each piezometer installed during the study.

Samples were obtained by attaching a suction bulb to the end of the piezometer tubing and pumping the sample directly into a pre-rinsed collection bottle. Each sample was analyzed for electrical conductivity using a standard laboratory cell and conductivity meter.

Additional large-volume porewater samples were collected from areas in close proximity to contaminated ground-water discharge (i.e., the Upper 100$\mathrm{H}$ and Old Hanford Townsite areas). Two methods of sample collection were employed. Samples of Old Hanford Townsite porewater from piezometer $\mathrm{H} 2$ were collected, without suction, by connecting a deflated disposable plastic bag to the piezometer tube. In this method, ground water flowed into the collecting bag with no risk of pulling river water down into the sample. When the bag had partially filled, the sample was transferred to collection bottles and the procedure was repeated until a sufficient sample volume was obtained. The advantage of using this method, as opposed to pumping the sample to the surface, is that it eliminated the possibility of an artificial hydraulic gradient being created, and thus, the possibility of drawing river water into the sample. The disadvantage is that coordination of sample collection with optimal ground-water discharge conditions was difficult and inefficient. Repeated attempts were made to sample remaining piezometers in the vicinity of the Old Hanford Townsite based on projected river flow. Site conditions varied with each attempt. Piezometers were sometimes completely submerged, sometimes exhibiting a relatively slow discharge, or were found on dry land and under ground-water recharge conditions.

In the Upper 100-H Area, hand-operated suction devices were used to withdraw porewater from piezometers $\mathrm{UH} 1$ and $\mathrm{UH} 14$ and transfer the sample to the sample containers. This method was successful though inefficient because the pump could not maintain a constant vacuum. This led to inconsistent sample volumes with each pump stroke. Samples from piezometer UH13 were collected by replacing the suction pump with a small hand-held suction bulb, which proved to be the most consistent method of sample collection.

Electrical conductivity was measured in the field immediately before and following sample collection to characterize the composition of the porewater and to note any changes that occurred during the sampling process. While employing the hand-operated suction technique during sample collection, the electrical conductivity of the porewater was measured periodically to 
determine if river water was being drawn into the sample. Specific conductivity was measured using a Myron "L" model DCH4 $\mathrm{pH} /$ conductivity meter. The instrument was calibrated prior to use each day in accordance with standard environmental surveillance procedures (PNL 1993).

All sampling equipment (excluding the disposable plastic bag) was thoroughly rinsed with river water and porewater prior to sample collection to avoid contamination. Flushing the equipment with porewater provided fresh water for sample collection. Talc-free surgical gloves were worn to minimize the potential for sample contamination. Samples for chemical analyses were collected in pre-cleaned bottles and immediately placed on ice in an ice chest. All samples were surveyed with a portable Geiger Muller counter to ensure their suitability for transport off-site. Samples were delivered to the lab as soon after collection as practical, well within recommended sample storage times. Chain-of-custody was maintained throughout the sample collection and transport process and was documented on appropriate forms with custodian transfer and sign-off. Field measurements were documented on field record forms.

Sample analytes for Old Hanford Townsite and Upper 100-H Area samples (Table 3.1) were selected based on findings of previous Columbia riverbank spring investigations (Dirkes and Hanf 1995) and reviews of contaminant concentrations observed in nearby ground-water monitoring wells (Dresel et al. 1995). Samples analyzed for Inductively Coupled Plasma (ICP) metals were preserved with $2 \mathrm{~mL}-\mathrm{HNO}_{3} / \mathrm{L}$. Tritium, ${ }^{90} \mathrm{Sr},{ }^{99} \mathrm{Tc}$, and isotopic uranium analyses were conducted by Quanterra Environmental Services, Richland, WA. Iodine-129 and chromium-VI analyses were performed by Pacific Northwest National Laboratory, Richland, WA. Metal and anion analyses were performed by DataChem Laboratories, Inc., Salt Lake City, UT. All analyses were performed on unfiltered samples. 
Table 3.1. Extended analyte list for Upper $100-\mathrm{H}$ and Old Hanford Townsite samples.

Analyte

Tritium

Strontium- $90^{2}$

Technetium-99
Method of Analyses

Tritium samples were counted directly with a liquid scintillation spectrometer, or the samples were enriched by alkaline electrolysis and then counted with the spectrometer.

Samples were acidified and boiled down, neutralized with ammonium hydroxide, and precipitated as the carbonate. Strontium- 90 was then leached with fuming nitric acid, scavenged with barium chromate and ammonium hydroxide, precipitated as a carbonate, transferred to a stainless-steel planchet, and counted with a low-background, gas-flow proportional counter. After 15 days, the ${ }^{90} \mathrm{Sr}$ decay product was separated and counted with a proportional counter.

Technetium-99 concentrations were determined using technetium separation by iron hydroxide precipitation followed by a carbonate precipitation. Further purification from interfering nuclides is performed by anion-exchange resin separation. The ${ }^{99} \mathrm{Tc}$ is counted by liquid scintillation spectrometry. 
Table 3.1. Extended analyte list for Upper $100-\mathrm{H}$ and Old Hanford Townsite samples. (contd)

Analyte

Iodine- $129^{\mathrm{b}}$ (cont)
Method of Analyses

The solution is then loaded on a source filament. This filament is a rhenium triple filament for negative thermal ionization. Thermal ionization mass spectrometry (TEMS) determines the I-125/I-129, I$129 / \mathrm{I}-127$ and I-125/I-127 ratios. Isotope dilution analysis calculations estimate the I-129 and I-127 from the I-125 spike level. Detection limit is about $1 \mathrm{E} 7$ atoms (1E-6 pCi).

Isotopic Uranium

Uranium in the water sample was adsorbed onto anion resin following wet ashing, purified, electrodeposited onto a stainless-steel planchet, and then counted with an alpha spectrometer.

Metals (total recoverable)

Samples were acid digested before analysis by SW846 method 6010, Inductively Coupled Plasma (ICP) Atomic Emission Spectroscopy for metal constituents. Metals reported in the analysis include: aluminum, antimony, arsenic, barium, beryllium, cadmium, calcium, chromium, cobalt, copper, iron, lead, magnesium, manganese, nickel, potassium, selenium, silver, sodium, tin, thorium, vanadium, and zinc.

Anions
Samples were introduced into an ion chromatograph and the anions of interest were separated and measured using standard D4327-88 (ASTM 1990) or Method 300.0 (O'Dell et al. 1984). Anions reported in the analysis include: bromide, chloride, fluoride, nitrate, nitrite, phosphate, and sulfate. 
Table 3.1. Extended analyte list for Upper $100-\mathrm{H}$ and Old Hanford Townsite samples. (contd)

Analyte

Chromium-VI
Method of Analyses

Adsorptive Stripping Voltametry. Diethylenetriaminepentacetic acid (DTPA) in a sodium nitrate/sodium acetate buffer was added to the sample and the sample was purged with nitrogen to remove oxygen. The $\mathrm{Cr}(\mathrm{VI})$-DTPA complex was pre-concentrated onto a fresh mercury drop by applying a negative potential $(-0.9 \mathrm{~V})$ during stirring of the solution. A voltammogram was recorded on a strip chart recorder during the stripping of the Cr(VI)-DTPA complex, the Cr(VI) concentration was estimated, and a spike of CR(VI) was added to the solution which increased the signal intensity by approximately two times. The analysis was repeated and the results recorded.

(a) Upper 100-H samples only.

(b) Old Hanford Townsite samples only. 


\subsection{Results and Discussion}

\subsection{General Electrical Conductivity Surveys}

River (surface water) values of electrical conductivity ranged from $111.4 \mu \mathrm{S} / \mathrm{cm}$ to $150.0 \mu \mathrm{S} / \mathrm{cm}$ (Table 4.1 ). The porewater electrical conductivity in some of the samples was about twice that of the river, indicating about $50 \%$ dilution as a minimum (Table 4.1). Measurements of hydraulic head relative to the river surface confirmed upward hydraulic potentials at most piezometers. The observed downward gradients were most likely due to rising river levels at the time of head measurements; these conditions were inconsistent with discharge conditions observed at the time of the probe survey. Also, at some locations hydraulic heads in many of the very shallow piezometers were only suitable for indicating low or nonexistent gradients. Lack of measurable differences in water levels relative to river level was probably due to the shallow depth of penetration of the piezometers and the highly permeable bottom materials.

There was good agreement between the bottom contacting electrical conductivity probe values (measured in situ) and porewater values that were collected from the piezometer and measured in the field or in the laboratory. Where electrical conductivity was predicted to be high based on the probe results, piezometer samples were correspondingly elevated in electrical conductivity (Table 4.1). However along the Locke Island shoreline, where the probe did not sense elevated electrical conductivity's, upward seepage potentials were later found to occur (Geist et al. 1997). In this area the porewater had apparently originated as river water and was no more electrically conductive than the river itself.

In order for the electrical conductivity probe to obtain accurate readings, it must maintain contact with the river bottom. It was assumed this would be difficult in the Columbia River because of the high discharge and predominantly large cobble substrate. In spite of these apparent difficulties we were aware of the contact with the substrate based on "the feel" of the handheld cable and on the slightly "noisy" record of the probe. Where bottom materials were fine-grained (e.g., silt and sand at White Bluffs Slough), the electrical conductivity was generally continuously elevated over distances as great as the area of upward-moving ground water that contained high concentrations of dissolved solids. However, where bottom materials were coarse and comprised of gravel or cobble material, electrical conductivity increases were not continuously elevated due to the bumpy contact of the probe with the riverbed.

Considering the high flows and cobble substrate in the Columbia River, the 
finding of electrical conductivity anomalies on the riverbed was somewhat surprising. The electrical conductivity record, even in cobble substrate having generally uniform upward flow, appeared as a few "hits" of elevated electrical conductivity in a background of lower river readings. Particularly where there was fast flowing surface water, these 'hits" may not have indicated the complete size or intensity of the upwelling. But there does not seem to be a mechanism or condition that would produce "hits" on a cobble-bottomed river without the presence of more conductive water. The only possible mechanism is the presence of clay sediments, which are uncommon on the bed of this river. For example, Blanton et al. (1995) found that clay comprised only $4 \%$ of the dry weight of Hanford Reach sediments. 
Table 4.1. Piezometer field data collected immediately following installation of riverbed piezometers. If the meniscus in the piezometer tube was below the river level, the difference in level is indicated by a negative sign. Locations on Vernita Bar, White Bluff Slough, Hanford Townsite, and Upper 100-H correspond to the sites described in Figures 4.1-4.7. Some measures were not determined (ND).

Piezo I.D

$$
\text { Depth below }
$$

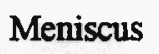

relative to river level

(cm)

\section{Vernita Bar}

VB1
VB2
VB3
VB4
VB5
VB6
VB7
VB8
VB9
VB10

VB launch

Upper 100-H

UH1

UH2

DSI4

UI4

UH13

UH14

UH launch

White Bluffs

Slough

WB1

WB2

WB3

WB launch

Hanford

Townsite

$\mathrm{H} 2$
$\mathrm{H} 4$
$\mathrm{H} 5$

below bottom

$\mathrm{ND}$
58.4
37.5
76.5
68.0
59.0
65.0
66.5
59.0
58.0
$\mathrm{ND}$

122.0

42.0

70.5

62.0

100.0

77.0

ND

75.0

70.0

85.0

ND

84.5

68.0

77.0

70.0

-22.7
0
$-1+0.5$
-2.0
-8.0

below river

$-1.0$

$-1.0$

$-0.5$

ND

\section{$-1.5$}

$+0.5$

$-1+0.0$

$-<1.0$

$-<2.0$

$+2.0$

ND

$-<1.0$

-0.3 to -0.4

$-3.5$

ND

$$
\begin{array}{r}
+21.0 \\
+8.5 \\
+3.8 \\
+7.0
\end{array}
$$

Electrical conductivity $(\mu \mathrm{S} / \mathrm{cm})$ of river at piezo.

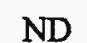

119.9

ND

117.9

120.0

120.0

116.1

ND

ND

111.4

119.9

ND

ND

134.0

134.0

ND

ND

113.5

122.5

128.5

118.2

116.0

124.0

131.0

150.0

128.4
Electrical

conductivity $(\mu \mathrm{S} / \mathrm{cm})$ of porewater
148.2

136.7

ND

233.0

130.0

193.6

125.7

129.2

137.9

140.1

ND

ND

ND

150.0

129.4

178.3

216.0

ND

251.0

257.0

155.1

ND 
Since the probe was always in contact with the bottom - the contact could be physically felt by the sampling team and the data record verified this - there is no issue regarding loss of bottom contact. Intermittent river values, because of large cobbles, did not bias the interpretation as long as it is recognized that in areas of high velocity, the probe might lift off the bottom, and one would record consistent river values of $45.5 \mathrm{mV}$ (about $120 \mu \mathrm{S} / \mathrm{cm}$ ). Without the sense of bottom-contact which is part of the operational procedure, the dark lines in the mid-channel could be interpreted as the probe being picked up off the bottom where velocities are $>2-3 \mathrm{~m} / \mathrm{s}$, and depths $>4-5 \mathrm{~m}$. Upwelling of bank storage water, combined with ground water moving from the west, may contribute to slightly elevated electrical conductivity levels closer to the shore. Piezometers placed in the channel to examine electrical conductivity and hydraulic potentials have so far substantiated the probe results where the midchannel records are about equal to the river values (D.R. Geist, unpublished data).

\subsection{Site Specific Results}

Data collected at the four sites are described below. Figures 4.1-4.7 depict conductivity measurements at individual sites. Each colored dot represents one measurement recorded from the electrical conductivity probe. The ranges of electrical conductivity, from low to high, are indicated with shades from black to white.

\subsubsection{Vernita Bar}

Vernita Bar was investigated as a control because it was upstream of any known source of ground-water contamination from Hanford operations. However, it was expected that discharging ground water at this site would be elevated in electrical conductivity because natural ground waters in the area have elevated electrical conductivity relative to the river (D.R. Geist, unpublished data). Results along Vernita Bar using the electrical conductivity probe showed elevated electrical conductivity values ( 52 to $56 \mathrm{mV}$ compared to river readings of approximately $40 \mathrm{mV}$ ) downstream of the bar near the eastern end (Figure 4.1). The electrical conductivity probe survey revealed hot spots at Vernita Bar where they might have been expected based on considerations of riverbed hydromorphometry. Perhaps because of rising river levels at the time of piezometer sampling, the gradients in the eastern end anomaly were, with two exceptions, downward (Table 4.1). However, piezometers VB4 to VB6, located at the eastern end, gave values of electrical conductivity ranging from 1.1 to nearly twice river values (Table 4.1). This 
confirmed that the probe had targeted an area of upwelling ground water. In this study area, it is likely that natural ground water with elevated electrical conductivity upwells to the river, possibly influenced by Priest Rapids Dam approximately $7 \mathrm{~km}$ upstream. No chemical or radiological analyses were conducted on porewater from Vernita Bar.

During a period of rising water, a transient channel was observed to be forming on the lower end of Vernita Bar. Piezometers were installed in the upper and lower end of this channel, which was forming as a result of the river over-topping the bar from a shoreline embayment to a point in the main river channel some $750 \mathrm{~m}$ downstream. The river gradient along the length of this channel was at least $1 \mathrm{~m} / 750 \mathrm{~m}(0.1 \%)$. Hydraulic head measurements made in these piezometers showed downwelling of river water into the riverbed along the length of the channel. Localized variations in potential within this channel may occur because of spatial variations in sediment permeability and the longitudinal profile of the river surface. For example, we observed recharge at the upstream end of the channel (downward potentials at VB7 to VB 10, Table 4.1 ), predominantly horizontal flow in the middle section (zero potential at VB3), and discharge at the lower end (elevated electrical conductivity at VB4 to VB6, Table 4.1).

\subsubsection{Upper and Lower 100-H}

Figure 4.2 shows the results obtained from more than $6 \mathrm{~km}$ of electrical conductivity measurements at the Upper and Lower 100-H Area. There was one significant anomaly at the Lower $100-\mathrm{H}$ Area shown by three $1 \mathrm{~km}$-long survey lines colored yellow and orange in the southeastern part of the survey area (Figure 4.3). The part of the anomaly shown in yellow measured 56 to 60 $\mathrm{mV}$, where the river water was only $47.9 \mathrm{mV}(113.5 \mu \mathrm{S} / \mathrm{cm})$. Because this large anomaly was offshore, piezometers were not installed during this 10-day study. These survey lines were situated slightly offshore of the $100-\mathrm{H}$ outfall structure where elevated chromium levels were found in the riverbed and were correlated with high electrical conductivity (Hope and Petersen 1996). 
Figure 4.1. Electrical conductivity measurements - Vernita Bar Area. 


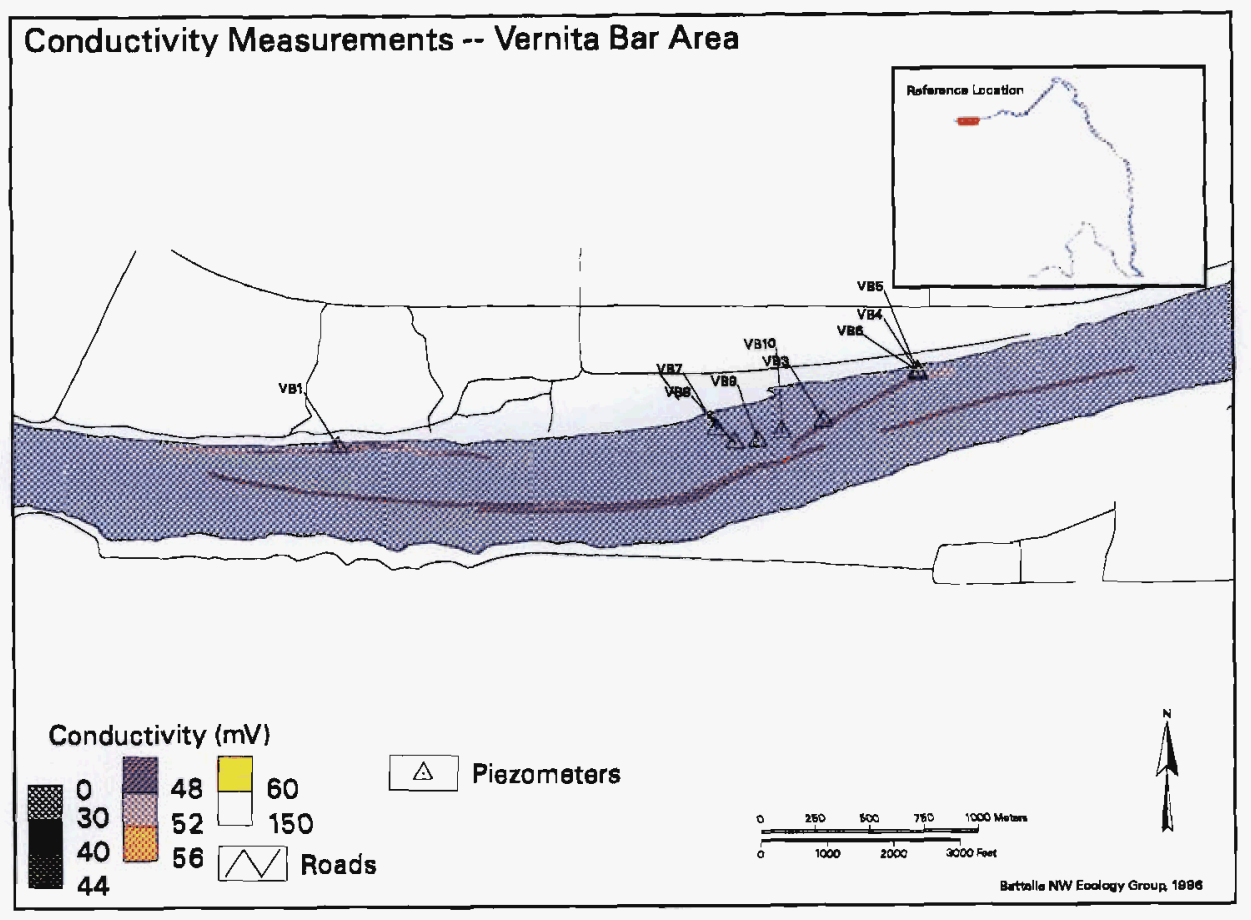


Figure 4.2. Electrical conductivity measurements - Upper and Lower 100-H Areas. 


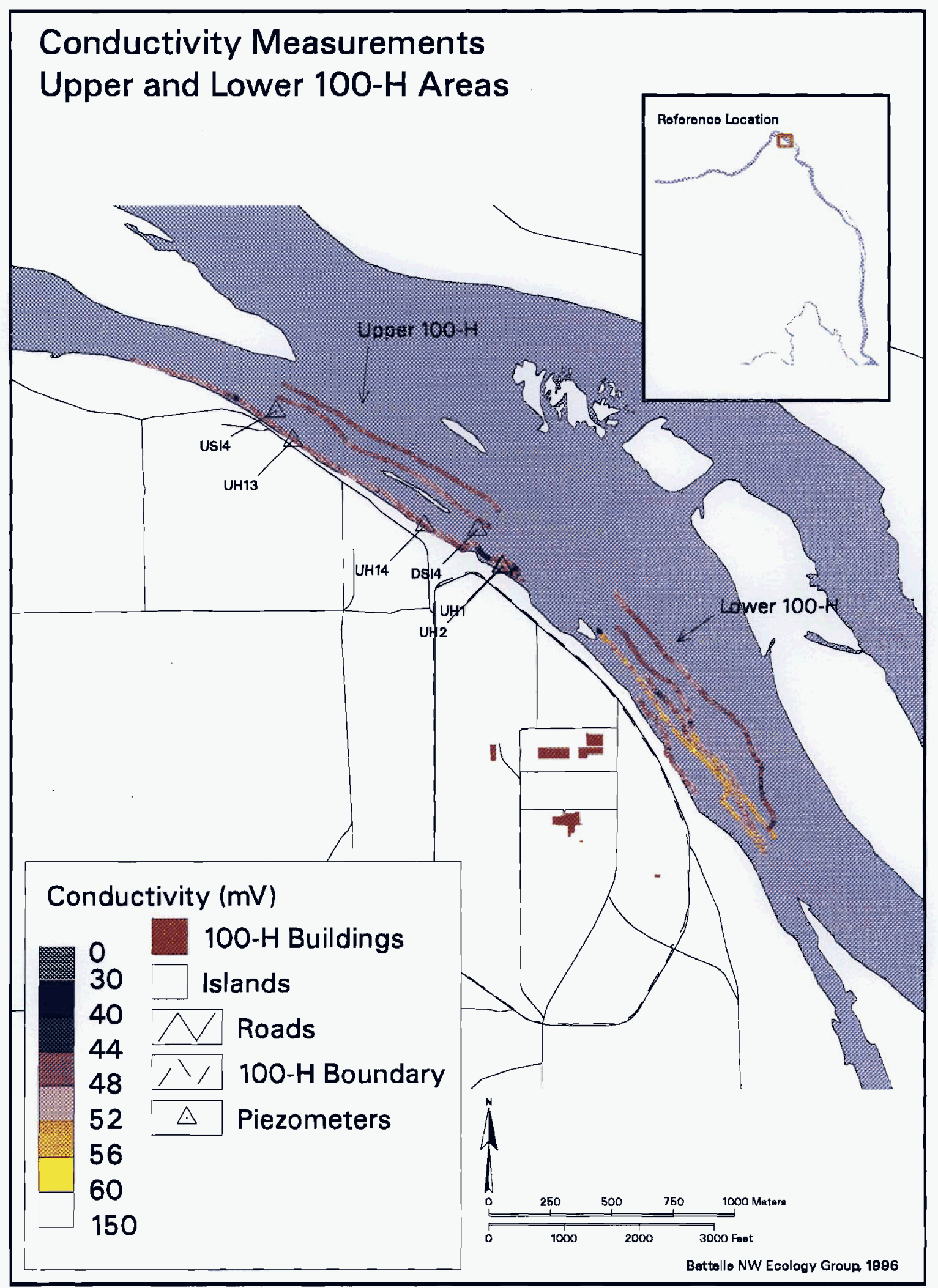


PNNL-11516

Figure 4.3. Electrical conductivity measurements - Lower 100-H Area. 


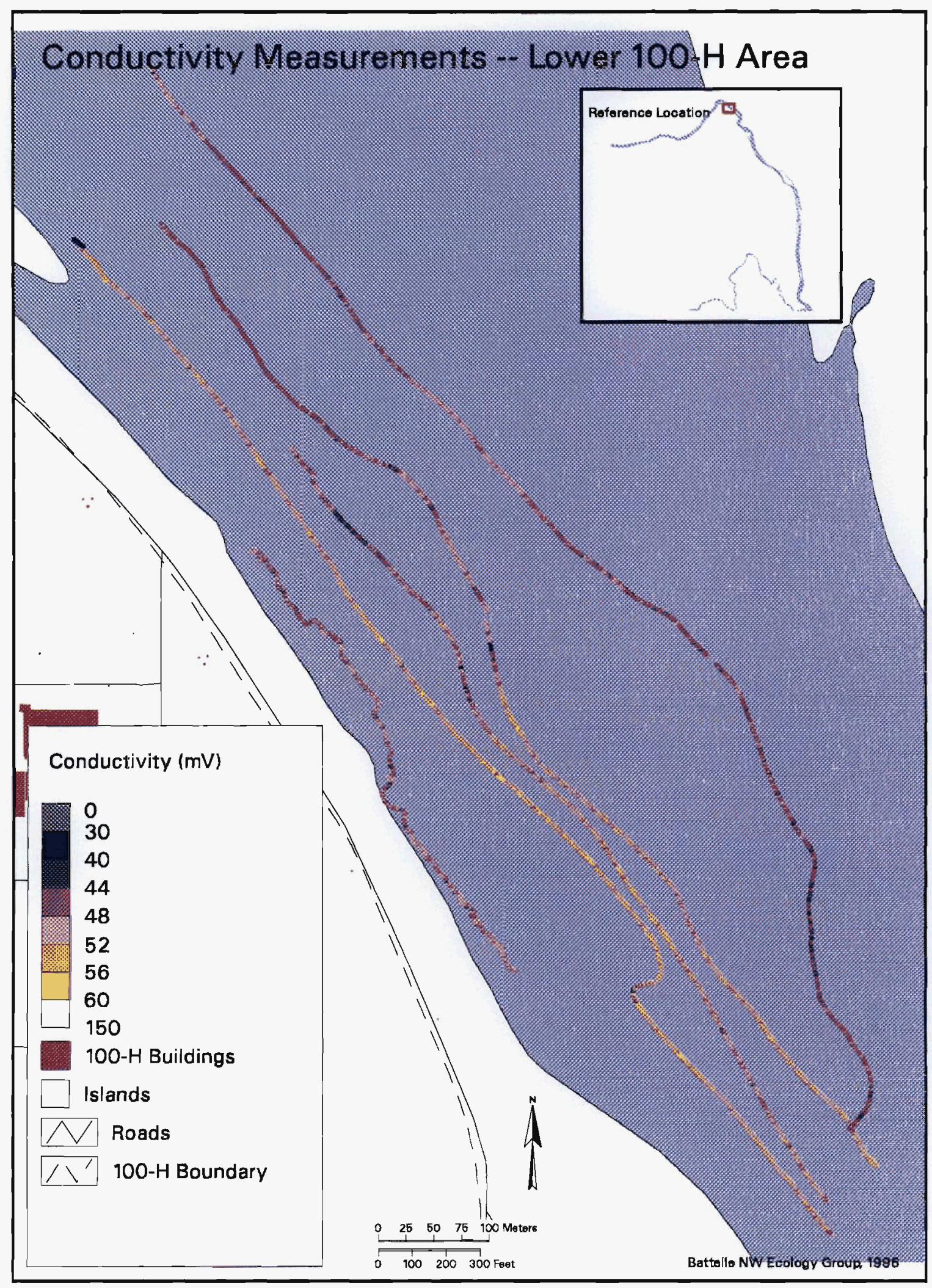


Electrical conductivity values of piezometers placed in the shallow subsurface sediments near the 100-H outfall as part of other studies revealed high dissolved solids ground water (Hope and Peterson 1996; 200-300 $\mu \mathrm{S} / \mathrm{cm}$ results in Geist et al. 1997). Hope and Peterson (1996) discuss the correlation between high electrical conductivity and chromium at this site. Based on point sampling done by scuba divers, Hope and Peterson (1996) discerned a small discharge area. However since the probe detected moderately elevated levels all along this section, the area may be larger and more significant than the previous point sampling suggested. This area is also a salmon spawning area, and is of concern because of its close proximity to the known ground-water plume of chromium and the evidence, however sparse, of ground-water discharge at this locality. Because elevated chromium has already been reported in the vicinity of this anomaly and the site is near a salmon spawning area, further effort with the electrical conductivity probe to define this area and the installation of piezometers to determine the hydrogeochemical nature of this anomaly may be warranted.

Figure 4.4 shows the electrical conductivity probe results from the Upper 100-H Area. Piezometers UH1 and UH2 were placed near, but not on, an electrical conductivity anomaly found in the Upper 100-H Area. At the time the anomaly was located with the electrical conductivity probe, the water depth was approximately $2 \mathrm{~m}$, and it was possible to install piezometers only inshore of the anomaly. However, even at this location the porewater sampled by $\mathrm{UH} 1$ was highly conductive with a value of $187 \mathrm{mS} / \mathrm{cm}$ (Table 4.1 ). UH13 was placed near the upstream end of the Upper 100-H Area, and UH14 was placed in a previously known shoreline seep. Initial electrical conductivity at UH13 was $178.3 \mathrm{mS} / \mathrm{cm}$ (Table 4.1 ), and on $11 / 2 / 95$ it was $247 \mathrm{mS} / \mathrm{cm}$. Electrical conductivity at UH14 was $139 \mathrm{mS} / \mathrm{cm}$ on $11 / 2 / 95$. The electrical conductivity probe did not indicate any electrical conductivity anomalies in these locations, but vertical gradients on the day the piezometers were installed were generally low or non-existent at these piezometers. These low flow potentials could be the result of the high river stage, which affects the flow potential (Geist et al. 1997). In other words, electrical conductivity probe surveys conducted at a high river stage may not locate some upwelling zones. High electrical conductivity values found on subsequent sampling of UH13 were likely because the river stage was lower during the November sampling than during the time of the probe survey. 


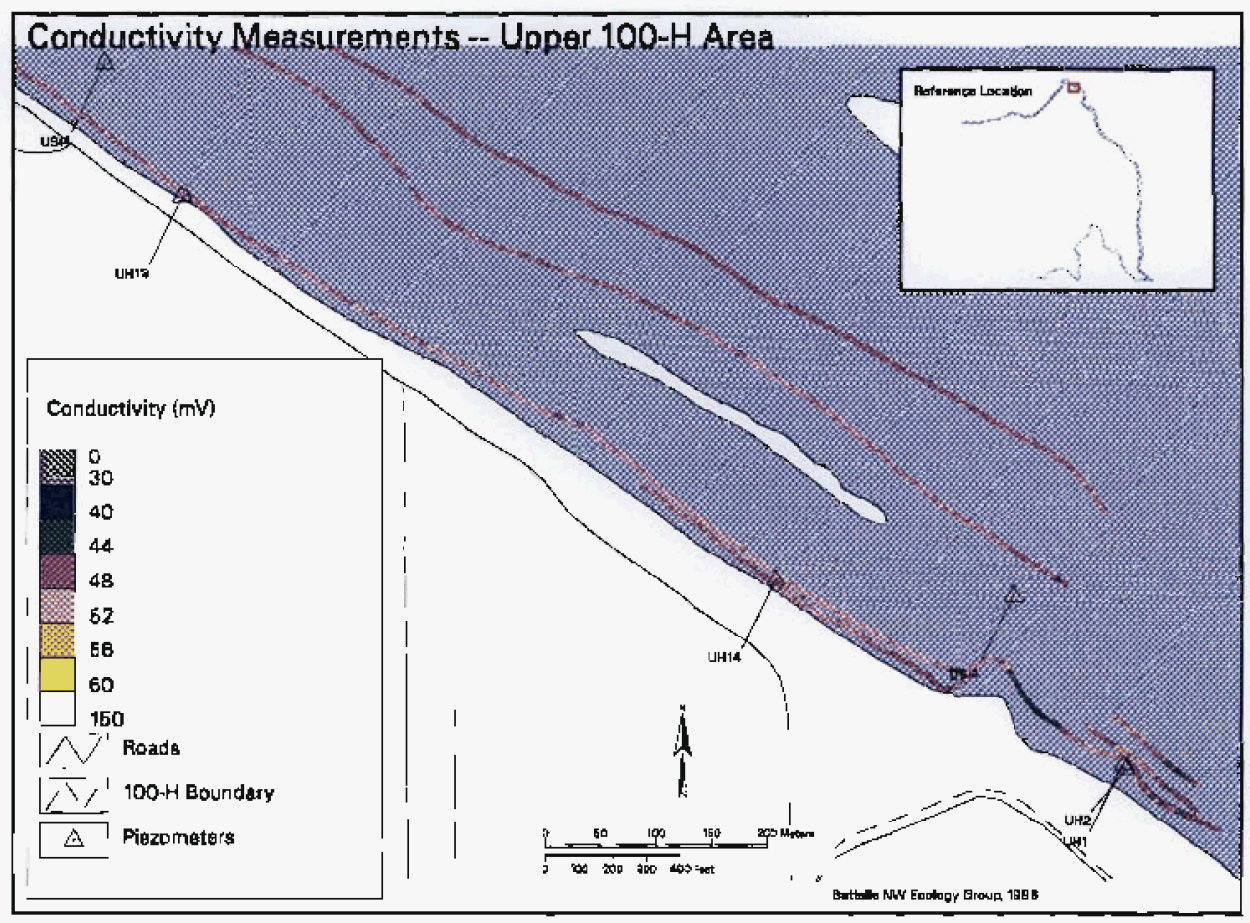


During the period from September through November, 1995, water samples were taken for radiological and non-radiological analysis at $\mathrm{UH} 1$ (9/28/95 [non-radiological only] and 10/30/95), UH13 (11/2/95), and UH14 $(11 / 2 / 95)$. No radiological constituents were significantly above ambient river levels at UH1, and none were above water quality standards (Table 4.2). Tritium at $\mathrm{UH} 13$ was $1,330( \pm 222) \mathrm{pCi} / \mathrm{L}$, and exceeded ambient river levels recorded at Vernita $(44.6 \pm 2.9 \mathrm{pCi} / \mathrm{L})$. However, this was well below the concentration that would produce a 4 mrem effective dose equivalent $(20,000$ $\mathrm{pCi} / \mathrm{L}$; Dirkes and Hanf 1995, 1996). Other isotopic results that exceeded the ambient river levels included isotopes of uranium at $\mathrm{UH} 13$ and $\mathrm{UH} 14$, however the levels were below the sitewide protection standard for total uranium of 13.4 pCi/L (Dirkes and Hanf 1995, 1996). 
Table 4.2. Results of radiological analysis for tritium, strontium-90 ( ${ }^{90} \mathrm{Sr}$ ), isotopic uranium $\left({ }^{234} \mathrm{U},{ }^{235} \mathrm{U}\right.$, and $\left.{ }^{238} \mathrm{U}\right)$, and technetium-99 $\left({ }^{99} \mathrm{Tc}\right)$ from unfiltered water samples taken from piezometers near the Old Hanford Townsite (H2) and Upper 100-H Area (UH1, UH13, and UH14). Values in parentheses for the piezometers are \pm 2 times total propagated analytical uncertainty. Piezometers were sampled one time only during the period September through November, 1995. Mean river concentrations are reported as the average of monthly water sample composites taken at Priest Rapids Dam from 1990 through 1994; values in parentheses for the river samples are \pm 2 standard errors of the mean.

\begin{tabular}{|c|c|c|c|c|c|}
\hline \multirow[b]{2}{*}{ Constituent } & \multicolumn{4}{|c|}{ Piezometers } & \multirow{2}{*}{$\begin{array}{l}\text { Mean } \\
\text { River } \\
(\mathrm{pCi} / \mathrm{L})\end{array}$} \\
\hline & $\begin{array}{c}\mathrm{H} 2 \\
(\mathrm{pCl} / \mathrm{L})\end{array}$ & $\begin{array}{r}\text { UH1 } \\
\text { (pCi/L) } \\
(\mathrm{p} \text { ( }\end{array}$ & $\begin{array}{c}\text { UH13 } \\
\text { (pCi/L) }\end{array}$ & $\begin{array}{c}\mathrm{UH} 14 \\
(\mathrm{pCi} / \mathrm{L})\end{array}$ & \\
\hline Tritium & $\begin{array}{l}120,000 \\
(8,850)\end{array}$ & $\mathrm{ND}^{\mathrm{a}}$ & $\begin{array}{l}1,330 \\
(222)\end{array}$ & $\mathrm{ND}^{a}$ & $\begin{array}{l}44.6 \\
(2.9)\end{array}$ \\
\hline Sr-90 & $\mathrm{NA}^{\mathrm{b}}$ & $\mathrm{ND}^{\mathrm{a}}$ & $\mathrm{ND}^{\mathrm{a}}$ & $\mathrm{ND}^{3}$ & $\begin{array}{c}0.086 \\
(0.007)\end{array}$ \\
\hline U-234 & $\begin{array}{c}1.80 \\
(0.22)\end{array}$ & $\begin{array}{c}0.26 \\
(0.06)\end{array}$ & $\begin{array}{c}0.51 \\
(0.08)\end{array}$ & $\begin{array}{c}1.44 \\
(0.18)\end{array}$ & $\begin{array}{c}0.24 \\
(0.01)\end{array}$ \\
\hline $\mathrm{U}-235$ & $\begin{array}{c}0.06 \\
(0.02)\end{array}$ & $\mathrm{ND}^{2}$ & $\begin{array}{c}0.03 \\
(0.02)\end{array}$ & $\begin{array}{c}0.06 \\
(0.02)\end{array}$ & $\begin{array}{c}0.01 \\
(0.002)\end{array}$ \\
\hline $\mathrm{U}-238$ & $\begin{array}{c}1.09 \\
(0.15)\end{array}$ & $\begin{array}{c}0.26 \\
(0.06)\end{array}$ & $\begin{array}{c}0.48 \\
(0.08)\end{array}$ & $\begin{array}{c}1.19 \\
(0.16)\end{array}$ & $\begin{array}{c}0.19 \\
(0.01)\end{array}$ \\
\hline Tc-99 & $\begin{array}{l}109.0 \\
(12.2)\end{array}$ & $\mathrm{ND}^{\mathbf{a}}$ & $\mathrm{ND}^{\mathrm{a}}$ & $\mathrm{ND}^{\mathrm{a}}$ & $\begin{array}{c}-0.19 \\
(0.33)\end{array}$ \\
\hline
\end{tabular}

Non-detection; less than 2 total propagated analytical uncertainty for the sample.

${ }^{\mathrm{b}}$ No analysis performed. 
Analyses for the piezometers from the Upper 100-H Area revealed a total chromium level in UH1 of $1,900( \pm 798) \mu \mathrm{g} / \mathrm{L}$ and $270( \pm 113) \mu \mathrm{g} / \mathrm{L}$ on $9 / 28 / 95$ and $10 / 30 / 95$, respectively, while hexavalent chromium was not detected (Table 4.3). Total chromium at $\mathrm{UH} 13$ was $87( \pm 37) \mu \mathrm{g} / \mathrm{L}$, and 170 $( \pm 71) \mu \mathrm{g} / \mathrm{L}$ at UH14. Hexavalent chromium levels were $20 \mu \mathrm{g} / \mathrm{L}$ at $\mathrm{UH} 13$ and $1.7 \mu \mathrm{g} / \mathrm{L}$ at UH14. The total chromium levels detected in $\mathrm{UH} 1$ and $\mathrm{UH} 14$ exceeded the federal primary drinking water standard for unfiltered total chromium (100 $\mu \mathrm{g} / \mathrm{L}$; EPA 822-R-96-001) while all samples analyzed for total chromium at upper 100-H exceeded the Washington State ground-water criteria for total unfiltered chromium $(50 \mu \mathrm{g} / \mathrm{L}$; Washington State minimum concentration limit). The sample for hexavalent chromium from UH13 is above the acute and chronic toxicity levels for hexavalent chromium set by Washington State (acute $16 \mu \mathrm{g} / \mathrm{L}$ and chronic $11 \mu \mathrm{g} / \mathrm{L}$, Washington Administrative Code 173-201A-0401995).

Table 4.3. Results of analysis for nitrate, total chromium, and hexavalent chromium from unfiltered water samples taken from piezometers near the Old Hanford Townsite (H2) and Upper 100-H Area (UH1, UH13, and UH14). Values in parentheses are \pm 2 total propagated analytical uncertainty; propagated uncertainty has not been determined for hexavalent chromium analysis. With the exception of $\mathrm{UH} 1$, all other piezometers were sampled one time only during the period September through November, 1995; UH1 was sampled on $9 / 28 / 95$ and $10 / 30 / 95$.

Piezometers

\begin{tabular}{|c|c|c|c|c|c|}
\hline Constituent & $\begin{array}{c}\mathrm{H} 2 \\
(\mu \mathrm{g} / \mathrm{L})\end{array}$ & $\begin{array}{c}\text { UH1 }(9 / 28) \\
(\mu \mathrm{g} / \mathrm{L})\end{array}$ & $\begin{array}{c}\text { UH1 } \\
(10 / 30) \\
(\mu \mathrm{g} / \mathrm{L})\end{array}$ & $\begin{array}{l}\text { UH13 } \\
(\mu \mathrm{g} / \mathrm{L})\end{array}$ & $\begin{array}{l}\mathrm{UH} 14 \\
(\mu \mathrm{g} / \mathrm{L})\end{array}$ \\
\hline Nitrate & $\begin{array}{l}28,000 \\
(5,880)\end{array}$ & $\mathrm{NA}^{\mathrm{a}}$ & $\begin{array}{l}450 \\
(94)\end{array}$ & $\begin{array}{c}5,600 \\
(1,180)\end{array}$ & $\begin{array}{c}850 \\
(179)\end{array}$ \\
\hline $\begin{array}{c}\text { Total } \\
\text { Chromium }\end{array}$ & $<3.7^{b}$ & $\begin{array}{l}1,900 \\
(798)\end{array}$ & $\begin{array}{c}270 \\
(113)\end{array}$ & $\begin{array}{c}87 \\
(37)\end{array}$ & $\begin{array}{l}170 \\
(71)\end{array}$ \\
\hline $\begin{array}{l}\text { Hexavalent } \\
\text { Chromium }\end{array}$ & $\mathrm{NA}^{\mathrm{a}}$ & $\mathrm{NA}^{\mathrm{a}}$ & $<0.5^{b}$ & 20 & 1.7 \\
\hline
\end{tabular}


The presence of chromium in riverbed porewaters was not surprising given the concentrations of chromium found in nearby ground-water monitoring wells. The highest concentration of filtered total chromium in the 100-H Area in 1994 was $300 \mu \mathrm{g} / \mathrm{L}$ for one sample. Other samples at the same monitoring well in 1994 ranged from 66 to $130 \mu \mathrm{g} / \mathrm{L}$ (Dresel et al. 1995). These wells are located some distance from the river in the center of a well-known chromium plume. Wells located near the river had average filtered chromium concentrations that ranged from 41 to $109 \mu \mathrm{g} / \mathrm{L}$ in 1994 (Dresel et al. 1995). However, because our porewaters were unfiltered, we cannot make direct comparisons between ground-water monitoring well values and our data. Mean total chromium in river samples from all sites in 1995 was $4.5 \pm 0.63$ $\mu \mathrm{g} / \mathrm{L}$ ( 2 times standard error of the mean).

Nitrate was detected in $\mathrm{UH} 1$ at a concentration of $450( \pm 94) \mu \mathrm{g} / \mathrm{L}$ on $10 / 30 / 95$. This is well below the $10,000 \mu \mathrm{g} / \mathrm{L}$ standard of the EPA and Washington State. Nitrate concentrations in $\mathrm{UH} 13$ and $\mathrm{UH} 14$ were below the $10,000 \mu \mathrm{g} / \mathrm{L}$ standard, although $\mathrm{UH} 13$ was slightly elevated above piezometers $\mathrm{UH} 1$ and UH14 (Table 4). Ground-water wells also show low nitrate levels throughout much of the $100-\mathrm{H}$ Area, although concentrations have been increasing in recent years (Dresel et al. 1995).

\subsubsection{Locke Island and White Bluffs Slough}

Figure 4.5 shows the results of the electrical conductivity surveys in the Locke Island/White Bluffs Slough areas. The Locke Island area is one of the current salmon spawning sites being investigated by the Pacific Northwest National Laboratory (PNNL). Approximately 40 piezometers were installed there following this sediment probe work (Geist et al. 1997). In agreement with the electrical conductivity survey results along the river side of the "island", porewater electrical conductivity levels above river values have not been observed in piezometers within salmon spawning areas (D.R. Geist, unpublished data). However, upward potentials have been observed in these 40 piezometers. The potentials are quite high in comparison to similar studies at other locations. These potentials may be due to the same pattern of bottom morphology and river gradient as noted in the channel instrumentation on Vernita Bar. At the upstream end (i.e., head) of river islands there is recharge into the riverbed. This provides water for sub-surface flow, but this water retains the electrical conductivity character of river water as it travels down gradient. Thus, even where there is upward movement of this water in response to hydraulic potentials, there is no elevation in electrical conductivity for the probe to detect. 

Bluffs Slough Area. 


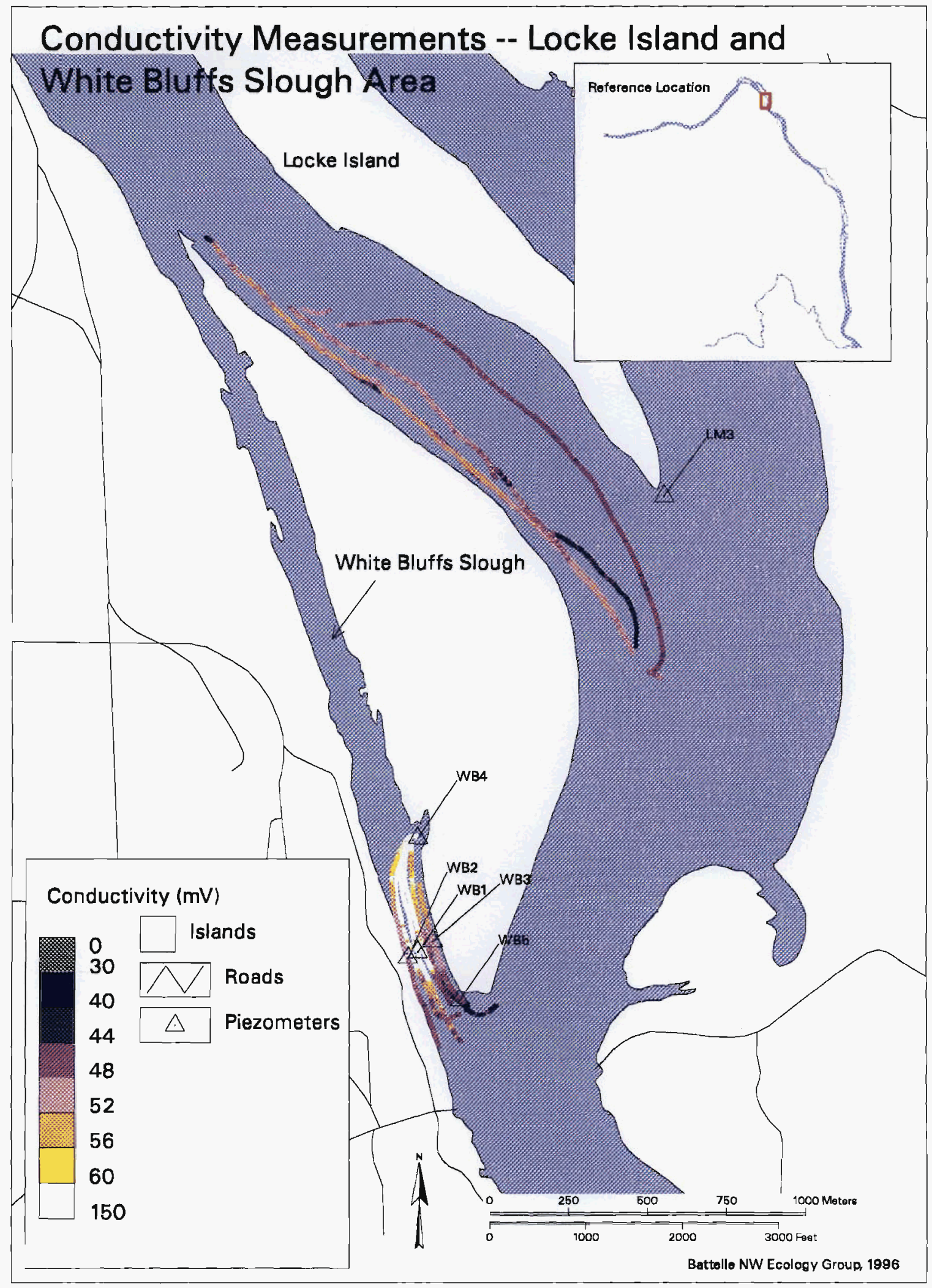


Electrical conductivity was slightly elevated along the right bank (looking downstream) of the river across from Locke Island near shore, slightly lower on the middle line and lower still on the line farthest offshore (Figure 4.5). This may be the result of flow from the west, driven partly by river level in the northwest trending section of the river. The site water table map supports this idea of recharge on the upstream part of the "horn" and discharge on the downstream part. Higher discharge rates are based on the general form of ground-water discharge patterns where most of the discharge in unconfined systems occurs near shore. From the Locke Island map it appears that the northward extension of the slough would intercept this water; however, this is not the case because the northward extension is dry during all but high water periods. At the time of this work, the slough was a dead end bay and the surface water was not connected to the river on the upper end as shown in the figure. Survey lines were run in water $0.4 \mathrm{~m}$ deep so the lines along the north, east and west shores provide an approximate outline of the shore at the time of the work. Therefore, the elevated electrical conductivity on the right bank may be the result of the expected pattern of groundwater discharge.

Figure 4.6 is an enlargement showing the electrical conductivity of the riverbed along $4.2 \mathrm{~km}$ of survey lines in White Bluffs Slough. Remarkably elevated values of sediment electrical conductivity were observed in the center and north end of the slough. The lowest electrical conductivity found with the probe was measured on the east shore, where the ground-water flow was expected to be low, while the electrical conductivity in the center of the slough was the highest. Five piezometers were placed at various locations within the White Bluffs Slough near areas of elevated electrical conductivity (Figure 4.6). Piezometers WB1, WB2, and WB3 were placed in line with WB1 in the center of the slough, WB3 on the east shore and WB2 the west (Figure 4.6). This line of piezometers across the slough at WB1, WB2 and WB3 provided porewater electrical conductivities of $251.0,257.0$ and $155.1 \mu \mathrm{S} / \mathrm{cm}$, in that order. Electrical conductivities of porewaters from these piezometers confirmed the electrical conductivity probe survey results (Figure 4.6).

Ground water may focus on the slough because the slough acts as a "low head" region by virtue of its upriver extent, or because high permeability materials connect the slough to up-gradient areas to the west. Clearly the site water table maps show that the area to the west is up-gradient and the contours are parallel to the slough (Dresel et al. 1995). Also, the probe may function better in recording discharge zones where it is moved through softer sediments. The slough bottom was blanketed by sand and silt as compared with cobble in the main never channel.

None of the White Bluff piezometers were successfully sampled for water quality as the slough was too high on subsequent return visits. 
Figure 4.6. Electrical conductivity measurements - Locke Island Area. 


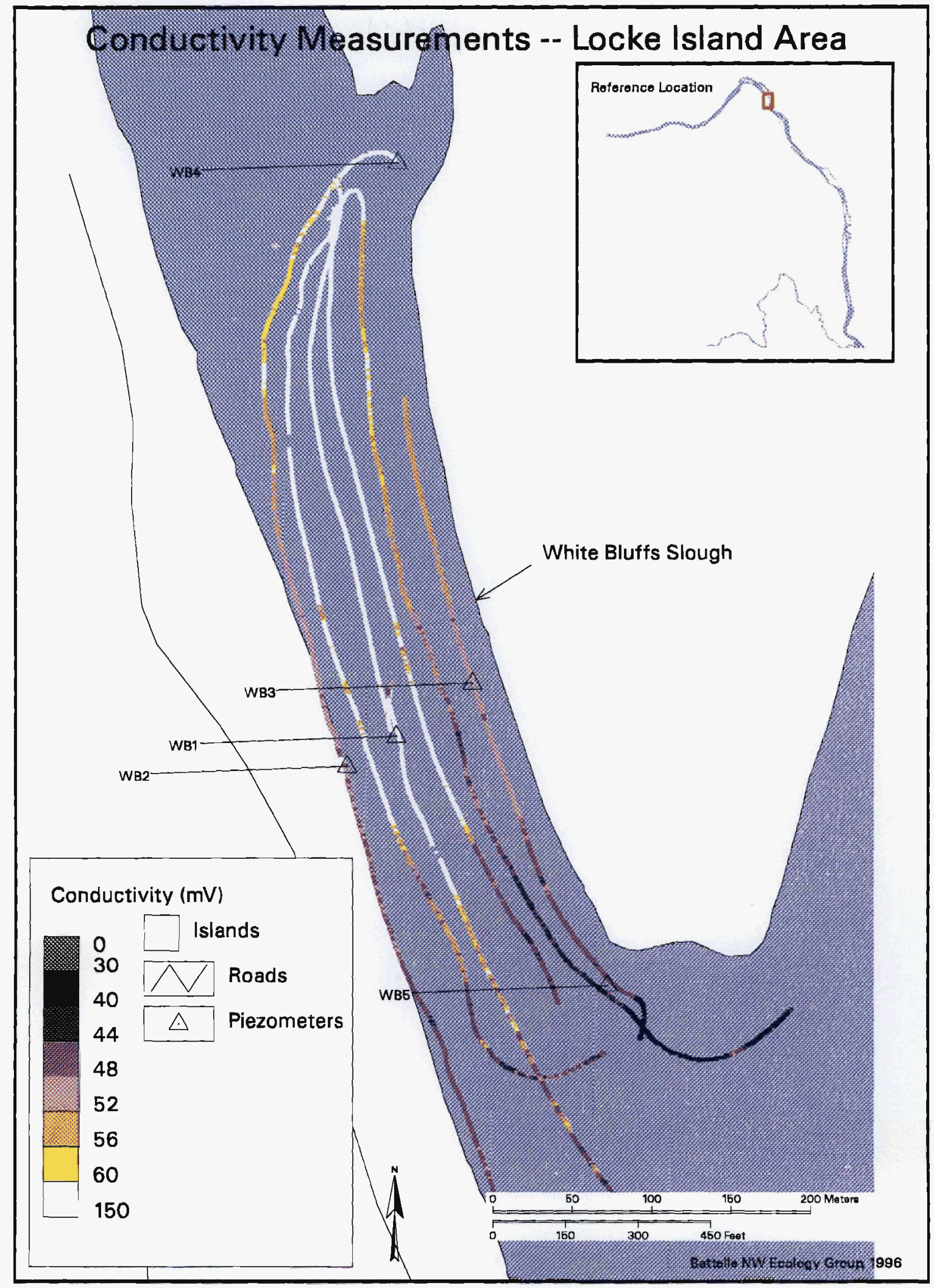




\subsubsection{Old Hanford Townsite}

We found several areas of likely discharge in the surveyed area (Figure 4.7), including many small areas and one that was notably continuous. These results may be related to the ground-water plume in the region, parts of which have tritium concentrations as high as $200,000 \mathrm{pCi} / \mathrm{L}$ (Evans et al. 1990; Dresel et al. 1996). Of the four piezometers installed at the Old Hanford Townsite, the electrical conductivity in all (190 to $291 \mu \mathrm{S} / \mathrm{cm})$ exceeded that of the river (124 to $150 \mu \mathrm{S} / \mathrm{cm}$ ). Piezometer $\mathrm{H} 2$ had an electrical conductivity at time of installation of $268 \mu \mathrm{S} / \mathrm{cm}$ as well as a relatively high discharge potential (Table 4.1). Tritium was measured at $\mathrm{H} 2$ at $120,000( \pm 8,850) \mathrm{pCi} / \mathrm{L}$ (Table 4.2). This is well above the $20,000 \mathrm{pCi} / \mathrm{L}$ concentration that EPA has determined would yield an average annual dose of $4 \mathrm{mrem} / \mathrm{yr}$ (Dirkes and Hanf 1996), and is similar to concentrations reported from wells sampled along the Old Hanford Townsite (Dresel et al. 1995). Concentrations in 10 wells located along the river in the vicinity of the Old Hanford Townsite show average levels of tritium in 1994 ranging from 103,000 to $192,000 \mathrm{pCi} / \mathrm{L}$. Our results from $\mathrm{H} 2$ show that the electrical conductivity probe provided us with a target within this plume and that ground-water concentrations may not be greatly diluted before arriving at the riverbed. The highest mean tritium concentrations observed in 1995 river transect water sampling were from the Old Hanford Townsite shoreline where concentrations were measured was $190( \pm 21.1)$ $\mathrm{pCi} / \mathrm{L}$ (Saldi and Dirkes 1996). The results from piezometer $\mathrm{H} 2$ were consistent with previous analysis of riverbank springs, which ranged from 6,340 to $173,000 \mathrm{pCi} / \mathrm{L}$ from 1990-1995 (7 samples, Dirkes and Hanf 1995).

Nitrate concentration in piezometer $\mathrm{H} 2$ was $28,000( \pm 5,880) \mu \mathrm{g} / \mathrm{L}$ (Table 4.3). This is above the $10,000 \mu \mathrm{g} / \mathrm{L}$ standard of the EPA and Washington State. Nitrate concentrations from river transect samples (Saldi and Dirkes 1996) were elevated along the Old Hanford Townsite shoreline and nitrate concentrations in riverbank springs from 1993-1995 ranged from 5,000 to $40,000 \mu \mathrm{g} / \mathrm{L}$ ( 3 samples, Dirkes and Hanf 1995). Average nitrate concentrations in wells adjacent to the river ranged from 31,000 to 41,000 $\mu \mathrm{g} / \mathrm{L}$ in 1994 (Dresel et al. 1995).

Piezometers $\mathrm{H} 4, \mathrm{H} 5$, and $\mathrm{H} 6$ were also placed in areas of elevated electrical conductivity as identified with the probe. The ground-water flow potentials at these piezometers were upward and electrical conductivity was elevated (Table 4.1). We suspect that groundwater with elevated dissolved solids is discharging in the areas identified by elevated electrical conductivity. We base this assumption on the fact that these piezometers detected high dissolved solutes in close proximity to the river (as evidenced by the high electrical conductivity), the sediments are highly permeable, and the piezometric heads were above river level. 
Figure 4.7. Electrical conductivity measurements - Hanford Townsite Area. 


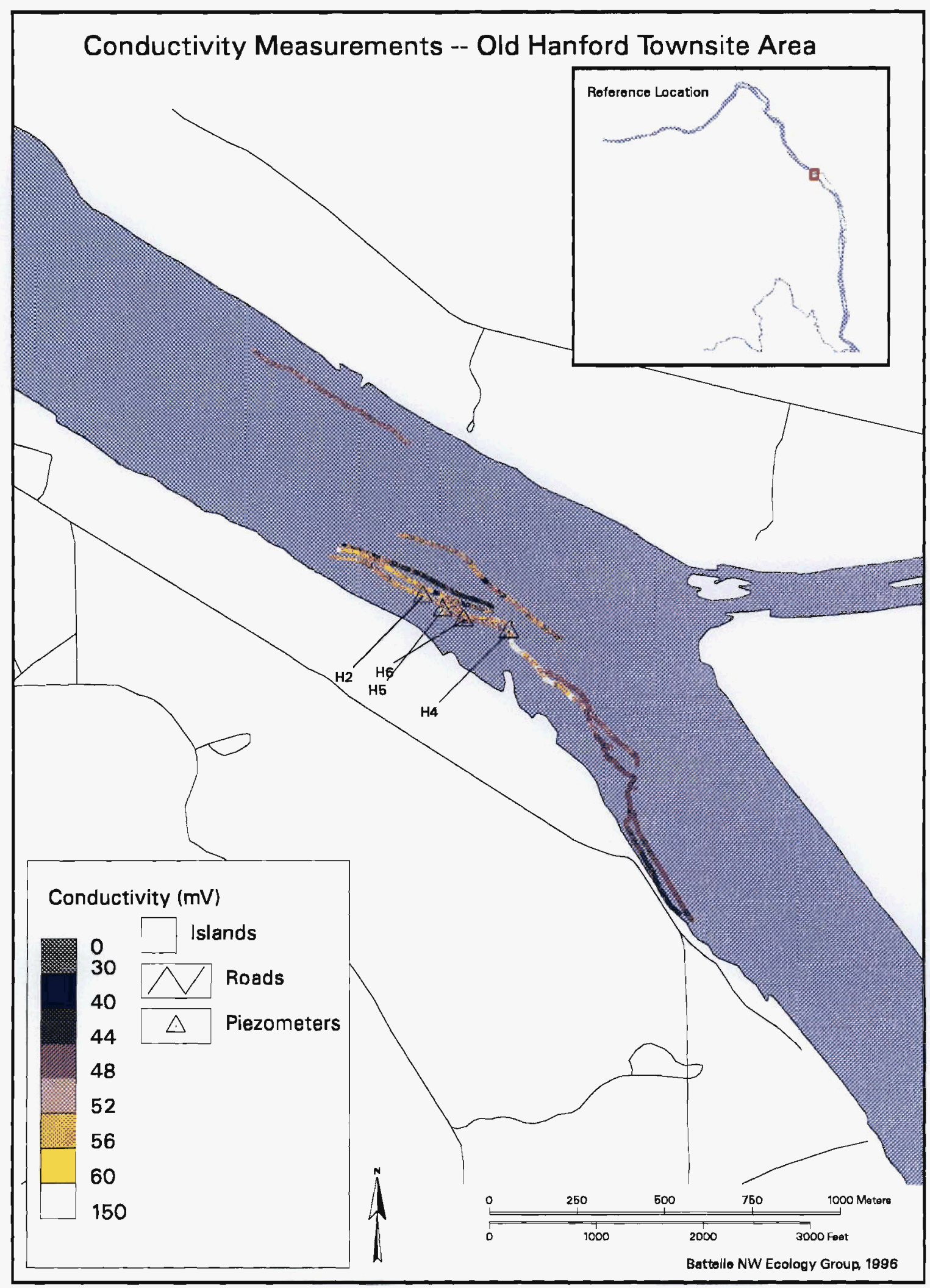




\subsection{Conclusions}

1. Electrical conductivity probe surveys were useful for generating qualitative maps of areas of elevated electrical conductivity on the riverbed. In every location of high electrical conductivity response by the electrical conductivity probe, riverbed porewater electrical conductivity was elevated relative to the overlying water. Thus the elevated electrical conductivity areas were shown to be the result of groundwater discharge.

2. Areas of discharge were not identified with the electrical conductivity probe if the discharging porewater was not elevated in electrical conductivity relating to the river. This was shown in the area of Locke Island, where the electrical conductivity probe readings did not indicate ground-water discharge, although ground-water potentials were upward. Porewaters in these areas were not significantly elevated in dissolved solids probably because they were river-waters that recharged the bed somewhere upstream and then traveled downstream in the permeable riverbed. This showed that the absence of elevated electrical conductivity values in the probe record does not guarantee the absence of ground-water discharge. In other words discharge areas may be missed if the electrical conductivity contrast between surface water and ground-water is small. The piezometers, installed in this study, generally had upward ground-water potentials. However, in some instances, the river was rising at the time water levels were measured, and in this case some ground-water potentials were downward. Porewater electrical conductivities ranged from a high of $291 \mu \mathrm{S} / \mathrm{cm}$ (H4 below the Old Hanford Townsite, Table 4.1) to values merely $10 \%$ above the ambient river value.

3. This application on the Columbia River demonstrated that even in a large turbulent river system with cobble bottoms and high currents this technique is effective in locating ground-water discharge areas. The probe was able to detect discharge even where the current was $2 \mathrm{~m} / \mathrm{s}$. Based on our results, it appears that identification of discharge areas may be possible where the difference in electrical conductivity between surface and ground water is less than a factor of two.

4. Probe performance was affected by the large cobbles and currents in the Columbia River. Some records included measurements, not of the water film at the sediment water interface, but of the river water itself. However, the "hits" were shown to be real highs in electrical conductivity. The probe is useful for locating upwelling areas where there is a difference in ground water and surface water electrical conductivity.

5. Now that discharge target areas have been identified, additional assessment 
work can be conducted. Samples may be collected at existing piezometers, or additional piezometers can be installed at locations using the existing database and global positioning system. It may be particularly useful to investigate the large anomalies in the 100-H Area and adjacent to the Old Hanford Townsite. Recently developed piezometer placement techniques (e.g. Lee and Harvey 1996; Geist et al. 1997) now make it feasible to install piezometers in offshore areas using anchored boats rather than the potentially dangerous practice of scuba diving. Recent efforts by one of the authors (D.R. Geist) has demonstrated that piezometers can be installed from boats in water depths exceeding $2 \mathrm{~m}$ in the middle of the Hanford Reach river channel. New piezometer installation methods may provide a safer, more cost-effective method for sampling ground-water discharges of chromium in the offshore regions of the $100-\mathrm{H}$. These methods will also provide a means to make measurements of hydraulic potentials and hydraulic conductivity so that estimates of the transport of chromium into the river can be made.

6. Nearshore discharge can be transient in both time and space. Mixing, dilution and even shifting of discharge locations can create difficulties in studying nearshore discharge where an unsaturated zone fills during rising river levels and drains during falling river levels. In these locations porewaters can be a mix of both surface water and ground water. However delineating an area of discharge with the electrical conductivity probe could be used to guide detailed work at the toe of a major groundwater plume. This would be groundbreaking because it would provide independent estimates of flux, comparable to the Darcy-based estimates that are routinely obtained within ground-water plumes. It should be noted that offshore discharge areas are not likely subject to the diluting effects of river-stage changes, although they are subject to changes in the overlying current regime and to changes in bedform topography.

7. The electrical conductivity probe identified several previously unknown ground-water discharges of chromium as shown with the piezometers placed in anomalies near the 100-H Area. Far more potential discharge areas were identified than could be tested during this 10-day study. Based on the success of this first application, it may now be possible to obtain funds to use the electrical conductivity probe for detailed mapping of a ground-water discharge area along the Hanford Reach. 


\subsection{References}

American Society for Testing and Materials (ASTM). 1990. Annual Book of ASTM Standards. Philadelphia, Pennsylvania.

Blanton, M.L., W.W. Gardiner, and R.L. Dirkes. 1995. Environmental monitoring of Columbia River sediments: Grain-size distribution and contaminant association. PNL-10535, Pacific Northwest Laboratory, Richland, Washington.

Dahm, C., and H.M. Valett. 1996. Hyporheic zones. Pages 107-119 in Hauer, F.R., and G.A. Lamberti, editors, Methods in Stream Ecology, Academic Press, San Diego.

Dirkes, R.L. 1990. 1988 Hanford riverbank springs characterization report. PNL-7500, Pacific Northwest National Laboratory, Richland, Washington.

Dirkes, R.L., and R.W. Hanf. 1995. Hanford Site environmental report for calendar year 1994. PNL-10574, Pacific Northwest Laboratory, Richland, Washington.

Dirkes, R.L., and R.W. Hanf. 1996. Hanford Site environmental report for calendar year 1995. PNNL-11139, Pacific Northwest National Laboratory, Richland, Washington.

Dresel, P.E., and nine co-authors. 1995. Hanford Site ground-water monitoring for 1994. PNL-10698, Pacific Northwest Laboratory, Richland, Washington.

Dresel, P.E., and seven co-authors. 1996. Hanford Site ground-water monitoring for 1995. PNNL-11141, Pacific Northwest National Laboratory, Richland, Washington.

Evans, J.C., R.W. Bryce, D.J. Bates, and M.L. Kemner. 1990. Hanford Site groundwater surveillance for 1989. PNL-7396, Pacific Northwest Laboratory, Richland, Washington.

Freeze, R.A. and J.A. Cherry. 1979. Groundwater. Prentice Hall, Inc., Inglewood Cliffs, New Jersey. 
Geist, D.R., T.M. Poston, and D.D. Dauble. 1994. Assessment of Potential Impacts of Major Groundwater Contaminants to Fall Chinook Salmon (Oncorhynchus tshawytscha) in the Hanford Reach, Columbia River. PNL 9990. Battelle, Pacific Northwest Laboratory. Richland, Washington.

Geist, D.R. 1995. Hanford Reach: What do we stand to lose? Illahee $11: 130-141$.

Geist, D.R., M.C. Joy, D.R. Lee, and T. Gonser. 1997. A new method for installing piezometers in large cobble-bed rivers. Annual Progress Report, Part C, Bonneville Power Administration, Portland, Oregon.

Hope, S.J., and R.A. Peterson. 1996. Pore water chromium concentration at 100-H reactor area adjacent to fall chinook salmon spawning habitat of the Hanford Reach, Columbia River. BHI-00345, Bechtel Hanford, Inc., Richland, Washington.

Lee, D.R. and J.A. Cherry. 1978. A field exercise on groundwater flow using seepage meters and mini-piezometers. J. Geol. Ed. 27:6-10.

Lee, D.R. and S.J. Welch. 1989. Methodology for locating and measuring submerged discharges: targeting tool, harpoon piezometer and more. In Proceedings Focus Conference on Eastern Regional Ground Water Issues. Co-sponsored by the Association of Ground Water Scientists and Engineers and Waterloo Centre for Groundwater Research (October 17-19, 1989).

Lee, D.R. and W.J. Beattie. 1991. Gamma survey probe for use on ocean, lake, estuary and river sediments. U.S. Pat. 5,050,525.

Lee, D.R., and R. Dal Bianco. 1994. Methodology for locating and quantifying acid mine drainage in ground waters entering surface waters. Paper presented at the International Land Reclamation and Mine Drainage Conference and the Third International Conference on the Abatement of Acidic Drainage, Pittsburgh, PA, April 24-29, 1994.

Lee, D.R., and F.E. Harvey. 1996. Installing piezometers in deepwater sediments. Water Resources Research 32: 1113-1117.

McCormack, W.D., and J.M.V. Carlile. 1984. Investigation of ground-water seepage from the Hanford shoreline of the Columbia River. PNL-5289, Pacific Northwest Laboratory, Richland, Washington. 
Neitzel, D.A., ed. 1996. Hanford Site National Environmental Policy Act (NEPA) Characterization. PNL-6415, Rev. 8, Pacific Northwest National Laboratory, Richland, Washington.

O'Dell, J.W., J.D. Pfaff, M.E. Gales, and G.D. McKee. 1984. Test method: The determination of inorganic anions in water by ion chromatography Method 300.0. EPA-600/4-84-017, Environmental Monitoring and Support Laboratory, U.S. Environmental Protection Agency, Cincinnati, Ohio.

Pacific Northwest Laboratory (PNL). 1993. Procedures for groundwater investigations. PNL-6894, Rev. 1, Pacific Northwest National Laboratory, Richland, Washington.

Peterson, R.E., and V.G. Johnson. 1992. Riverbank seepage of groundwater along the 100 areas shoreline, Hanford site. WHC-EP-0609, UC-703, Westinghouse Hanford Company, Richland, Washington.

Saldi, K.A., and R.L. Dirkes. 1996. Surface water and sediment surveillance. Pages 109-137 in R.L. Dirkes and R.W. Hanf (eds.), Hanford Site environmental report for calendar year 1995, PNNL-11139, Pacific Northwest National Laboratory, Richland, Washington.

Shiklomanov, I.A. 1993. World freshwater resources. Pages 13-24 in P.H. Gleik (ed.), Water in crisis, a guide to the world's freshwater resources. Oxford University Press, New York.

Strebin, R.S., Jr., F.P. Brauer, J.H. Kaye, M.S. Rapids, and J.J. Stoffel. 1988. Neutron activation and mass spectrometric measurement of ${ }^{129} I$. J. Radioanal. Nucl. Chem., Letters, 129(1): 59-73.

U.S. Department of Energy (DOE). 1992. Sampling and analysis of 100 area springs. DOE/RL-92-12, U.S. Department of Energy, Richland, Washington.

Vaux, W.G. 1968. Intragravel flow and interchange of water in a streambed. Fishery Bulletin 66:479-489. 


\section{Notice:}

This report is not to be listed in abstract journals. If it is cited as a reference, the source from which copies may be obtained should be given as:

Scientific Document Distribution Office (SDDO)

AECL

Chalk River, Ontario

Canada KOJ 110

Fax: (613)584-1745

Tel.: (613)584-3311

ext. 4623 